\title{
Nocardia jiangxiensis sp. nov. and Nocardia miyunensis sp. nov., isolated from acidic soils
}

Correspondence
Ying Huang
huangy@im.ac.cn

The genus Nocardia belongs to the family Nocardiaceae, a member of the suborder Corynebacterineae, proposed by Stackebrandt et al. (1997). At the time of writing, the genus encompasses 46 species with validly published names; the majority of these species have been described in the last 5 years by means of polyphasic taxonomic approaches (Maldonado et al., 2000; Yassin et al., 2001a, b; Kim et al., 2002; Zhang et al., 2003, 2004). Most of the novel species are associated with human and animal infections (Yassin et al., 2000a, b, 2003; Hamid et al., 2001; Kageyama et al., 2004a, b, c, d); nearly all of the remaining novel species are from soil collected from geographically diverse locations (Maldonado et al., 2000; Albuquerque de Barros et al., 2003; Li et al., 2004; Saintpierre-Bonaccio et al., 2004; Zhang et al., 2003, 2004).

Little is known about the functional roles of nocardiae in natural habitats, though it is clear that they form an integral part of the autochthonous soil microflora (Orchard, 1979, 1981). Nevertheless, there is evidence that nocardial species diversity in the soil ecosystem is greatly underestimated (Orchard \& Goodfellow, 1980; Wang et al., 1999; Maldonado

Published online ahead of print on 13 May 2005 as DOI 10.1099/ ijs.0.63644-0.

The GenBank/EMBL/DDBJ accession numbers for the 16S rRNA gene sequences of strains $117^{\top}$ and $43401^{\top}$ are AY639901 and AY639902, respectively.

Scanning electron micrographs of strains $117^{\top}$ and $43401^{\top}$ are available as a supplementary figure in IJSEM Online. et al., 2000). It is important to establish the species richness of nocardiae in natural habitats for ecological reasons and for industrial purposes, as novel nocardiae are a source of commercially significant bioactive compounds (Kinoshita et al., 2001; Bringmann et al., 2005). The aim of the present study was to determine the taxonomic status of two Nocardia-like strains isolated from soil.

Strain $117^{\mathrm{T}}$ was isolated from a pine-forest soil sample (about pH 5.5) collected in Miyun County, Beijing (China), and strain $43401^{\mathrm{T}}$ was isolated from rhizosphere soil (about $\mathrm{pH} 3.5$ ) of goose-grass (Eleusine indica) growing next to a copper mine in Wushan, Jiangxi Province, southern China. In each case, soil suspensions prepared using a dispersion and differentiation procedure (Wang et al., 2003) were inoculated onto plates of an acidified selective isolation medium (Huang et al., 2004), which were incubated for 3 weeks at $28^{\circ} \mathrm{C}$. The strains were maintained on oatmeal agar (ISP medium 3; Küster, 1959), adjusted to an initial pH of $5 \cdot 5$ using a citric acid $(0 \cdot 1 \mathrm{M}) / \mathrm{Na}_{2} \mathrm{HPO}_{4}(0 \cdot 2 \mathrm{M})$ buffer.

The colonial properties of the isolates were observed on modified Sauton's agar (Mordarska et al., 1972) and acidified oatmeal agar (as above) plates that had been incubated for 7 days at $28^{\circ} \mathrm{C}$. Micromorphological properties were recorded using samples taken from the Sauton's agar plates and examined by using light microscopy (Axioskop 20; Zeiss) and scanning electron microscopy (FEI QUANTA instrument). Well-established procedures were used to 
determine a range of phenotypic properties (Goodfellow, 1971). In addition, acid production from carbohydrates was determined using media and methods described by Gordon et al. (1974), use of sole carbon sources for energy and growth was assessed according to the methods of Yassin et al. (1995) and biochemical and biodegradation tests were performed using procedures described by Gordon \& Mihm (1957). Oatmeal agar adjusted to initial $\mathrm{pH}$ values of $3 \cdot 5$, $4 \cdot 5,5 \cdot 5,6 \cdot 5,7 \cdot 5,8 \cdot 5,9 \cdot 5$ and $10 \cdot 5$ using citric acid $(0 \cdot 1 \mathrm{M}) /$ $\mathrm{Na}_{2} \mathrm{HPO}_{4}(0 \cdot 2 \mathrm{M})$ and glycine $(0 \cdot 05 \mathrm{M}) / \mathrm{NaOH}(0 \cdot 05 \mathrm{M})$ buffer systems was used to test the ability of strains to grow at different $\mathrm{pHs}$. The chemotaxonomic properties of the isolates were determined by following standard chromatographic procedures as outlined by Zhang et al. (2003). Extraction of genomic DNA, PCR amplification of $16 \mathrm{~S}$ rRNA and purification of the PCR products from strains $117^{\mathrm{T}}$ and $43401^{\mathrm{T}}$ were carried out by following the procedures described by Rainey et al. (1996); the purified PCR products were sequenced directly, according to the method of Lu et al. (2001). The 16S rRNA gene sequences of the strains were aligned manually with corresponding nucleotide sequences of the type strains of Nocardia species, retrieved from the GenBank/EMBL/DDBJ databases, using CLUSTAL X 1.8 software (Thompson et al., 1997). Phylogenetic trees were inferred using the least-squares (Fitch \& Margoliash, 1967), maximum-likelihood (Felsenstein, 1981), maximum-parsimony (Kluge \& Farris, 1969) and neighbour-joining (Saitou \& Nei, 1987) tree-making algorithms from the PHYLIP suite of programs (Felsenstein, 1993). Evolutionary distance matrices were generated as described by Kimura (1980). The resultant unrooted tree topologies were evaluated by bootstrap analysis (Felsenstein, 1985) of the neighbour-joining method based on 1000 resamplings, using the SEQBOOT and CONSENSE options from the PHYLIP package.

Chromosomal DNA was extracted and purified from the two isolates and from the type strains of Nocardia nova and Nocardia pseudobrasiliensis. DNA-DNA relatedness values between the tested strains were estimated using the fluorometric microplate method of Ezaki et al. (1989). The hybridization experiments were carried out under stringent conditions in $50 \%$ formamide at $50{ }^{\circ} \mathrm{C}$. Fluorescence intensities were measured using a Fluostar Optima microplate reader (BMG LABTECH) at a wavelength of $360 \mathrm{~nm}$ for excitation and at $460 \mathrm{~nm}$ for emission. DNA-DNA relatedness values were calculated from quadruplicated hybridization experiments and expressed as means of the corresponding reciprocal values.

When the almost-complete 16S rRNA gene sequences of strains $117^{\mathrm{T}}(1405 \mathrm{nt})$ and $43401^{\mathrm{T}}(1409 \mathrm{nt})$ were examined, they were found to contain the signature nucleotides characteristic of the family Nocardiaceae (Stackebrandt et al., 1997) and of the genus Nocardia (Chun \& Goodfellow, 1995). It was apparent from the phylogenetic analyses that the two strains fell within the 16S rRNA Nocardia gene tree (data not shown). The organisms were also shown to have phenotypic properties consistent with their classification in the genus Nocardia (Goodfellow et al., 1999), i.e. the strains are aerobic, Gram-positive, partially acid-alcohol-fast actinomycetes that form extensively branched substrate mycelia that fragment into irregular, rod-shaped, nonmotile, rod-shaped elements (see Supplementary Fig. S1 in IJSEM Online). In addition, each strain produced whole-organism hydrolysates rich in meso-diaminopimelic acid, arabinose and galactose (wall chemotype IV sensu Lechevalier \& Lechevalier, 1970) and contained major amounts of diphosphatidylglycerol, phosphatidylethanolamine, phosphatidylinositol and phosphatidylinositol mannosides (phospholipid type II sensu Lechevalier et al., 1977), a predominance of hexahydrogenated menaquinones with eight isoprene units where the end two were cyclized, and fatty acid profiles consisting mainly of saturated, unsaturated and 10-methyl-branched components. They were also characterized by the presence of mycolic acids that comigrated $\left(R_{\mathrm{f}}\right.$ value around $\left.0 \cdot 47\right)$ with those from marker strains of Nocardia.

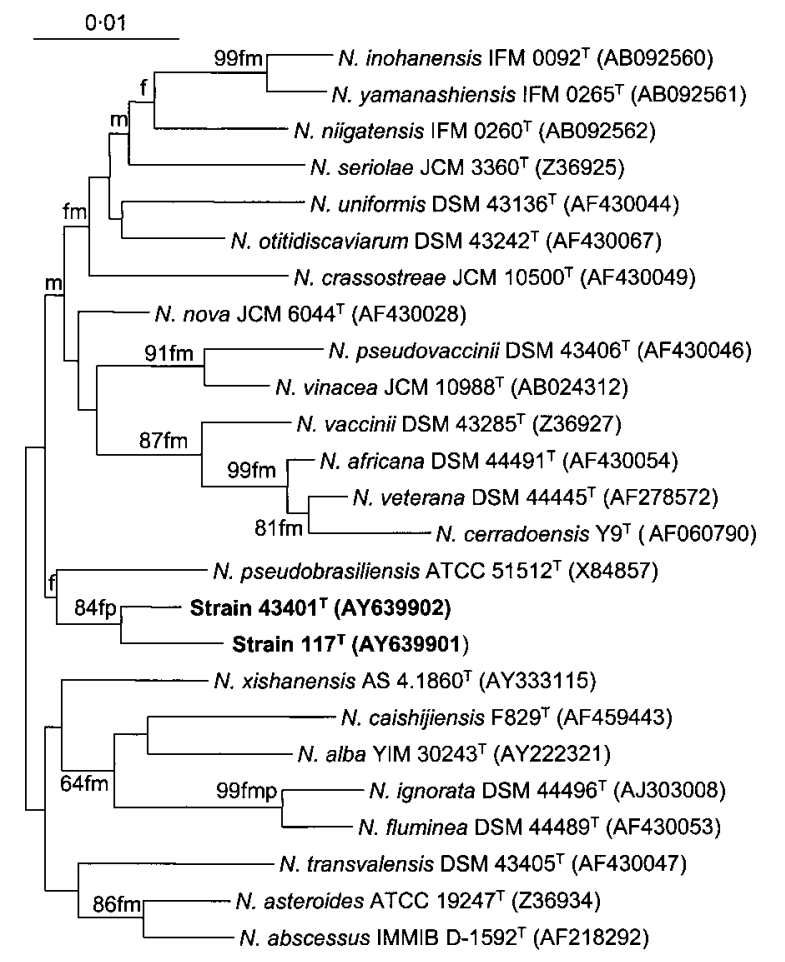

Fig. 1. An unrooted neighbour-joining tree (Saitou \& Nei, 1987), based on nearly-complete 16S rRNA gene sequences, showing the positions of strains $117^{\top}$ and $43401^{\top}$ amongst representatives of closely related Nocardia species. The symbols $f, m$ and $p$ denote branches that were also recovered using the least-squares (Fitch \& Margoliash, 1967), maximum-likelihood (Felsenstein, 1981) and maximum-parsimony (Kluge \& Farris, 1969) tree-making algorithms, respectively. Numbers at nodes indicate levels of bootstrap support based on a neighbour-joining analysis of 1000 resampled datasets; only values above $50 \%$ are given. Bar, 0.01 substitutions per nucleotide position. 
It is apparent from the abridged phylogenetic tree (Fig. 1) that the two strains form a phylogenetic branch that is supported by three out of the four tree-making algorithms and by a bootstrap value of $84 \%$ in the neighbourjoining analysis. The two organisms share a $16 \mathrm{~S}$ rRNA gene sequence similarity of $98.5 \%$, a value that corresponds to $15 \mathrm{nt}$ differences at 1405 locations. Each organism is most closely, albeit loosely, related to the type strains of $N$. nova and N. pseudobrasiliensis. Strain $117^{\mathrm{T}}$ shares $16 \mathrm{~S}$ rRNA gene sequence similarity of $98 \cdot 1 \%$ with $N$. nova JCM $6044^{\mathrm{T}}$ and $98.2 \%$ with N. pseudobrasiliensis ATCC $51512^{\mathrm{T}}$, values that are equivalent to 26 and $25 \mathrm{nt}$ differences at 1405 positions; the corresponding values for strain $43401^{\mathrm{T}}$ are $98 \cdot 7$ and $97.9 \%$, corresponding to 18 and $29 \mathrm{nt}$ differences at 1395 positions. Much higher 16S rRNA gene sequence similarities than these have been found between the type strains of Nocardia species shown to have DNADNA relatedness values well below the $70 \%$ threshold recommended for the delineation of genomic species (Wayne et al., 1987). The type strains of Nocardia brevicatena and Nocardia paucivorans, for instance, were found to share a $16 \mathrm{~S}$ rRNA gene sequence similarity of $99 \cdot 6 \%$ and had a DNA relatedness value of $61.9 \%$ (Yassin et al., 2000a).
It is evident from the DNA-DNA relatedness data that strains $117^{\mathrm{T}}$ and $43401^{\mathrm{T}}$ represent two distinct genomic species. These strains were found to have a mean DNADNA hybridization value of $58 \%$ and corresponding relatedness values below $55 \%$ with $N$. nova JCM $6044^{\mathrm{T}}$ (54\% with strains $117^{\mathrm{T}}$ and $46 \%$ with strain $43401^{\mathrm{T}}$ ) and N. pseudobrasiliensis ATCC $51512^{\mathrm{T}}\left(42 \%\right.$ with strain $117^{\mathrm{T}}$ and $39 \%$ with strain $43401^{\mathrm{T}}$ ). The two strains can also be distinguished from one another and from phylogenetically close relatives, including the type strains of $N$. nova and $N$. pseudobrasiliensis, by using a combination of phenotypic properties (Table 1).

It is clear from the genotypic and phenotypic data that strains $117^{\mathrm{T}}$ and $43401^{\mathrm{T}}$ merit recognition as novel Nocardia species: the names proposed for these novel taxa are Nocardia miyunensis sp. nov. and Nocardia jiangxiensis sp. nov., respectively.

\section{Description of Nocardia jiangxiensis sp. nov.}

Nocardia jiangxiensis (jiang.xi.en'sis. N.L. fem. adj. jiangxiensis referring to Jiangxi Province, southern China, the source of the type strain).

Table 1. Phenotypic characteristics that distinguish strains $117^{\top}$ and $43401^{\top}$ from one another and from the type strains of phylogenetically close Nocardia species

Strains: 1, strain $117^{\mathrm{T}} ; 2$, strain $43401^{\mathrm{T}} ; 3$, Nocardia abscessus DSM $44432^{\mathrm{T}}$; 4, Nocardia africana DSM 44491 ${ }^{\mathrm{T}}$; , Nocardia asteroides ATCC $19247^{\mathrm{T}} ; 6$, Nocardia crassostreae ATCC $700418^{\mathrm{T}} ; 7$, N. nova JCM $6044^{\mathrm{T}} ; 8$, Nocardia otitidiscaviarum NCTC 1934 ${ }^{\mathrm{T}}$; 9, N. pseudobrasiliensis ATCC $51512^{\mathrm{T}} ; 10$, Nocardia transvalensis DSM 43405 ${ }^{\mathrm{T}} ; 11$, Nocardia vaccinii DSM $43285^{\mathrm{T}} ; 12$, Nocardia vinacea JCM $10988^{\mathrm{T}}$; 13 , Nocardia xishanensis CGMCC $4.1860^{\mathrm{T}}$. Data were taken from this study and previous studies (Yassin et al., 2000b, 2001b; Albuquerque de Barros et al., 2003; Zhang et al., 2003, 2004). +, Positive; -, negative; d, doubtful; ND, not determined.

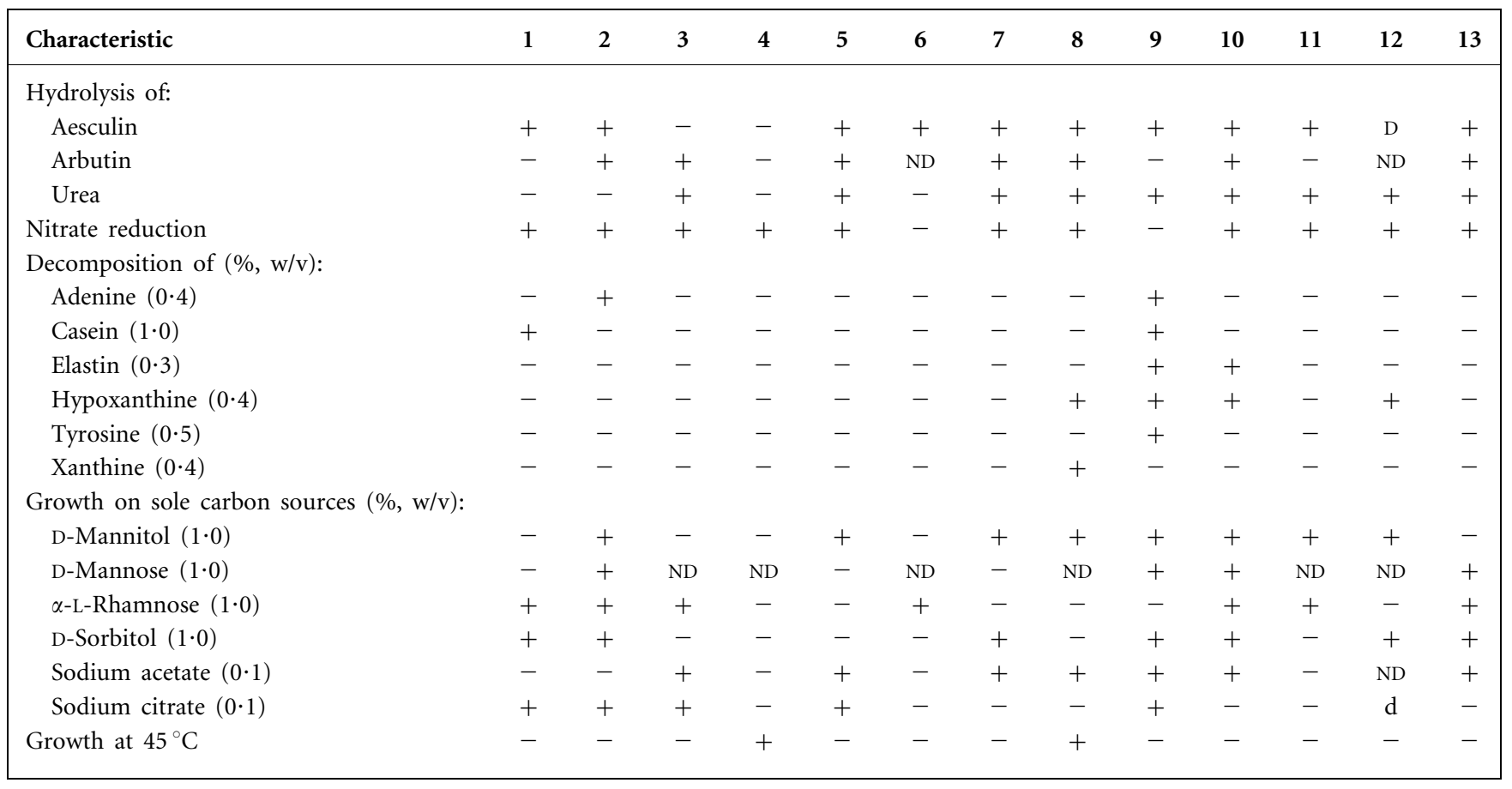


Aerobic, Gram-positive, catalase-positive, partially acidalcohol-fast, non-motile actinomycete that forms an extensively branched substrate mycelium that fragments into rod-shaped elements. A pinkish white to orange substrate mycelium bears sparse to abundant, white to pink aerial hyphae on modified Sauton's agar. A yellowish brown substrate mycelium carrying white aerial hyphae is formed on oatmeal agar at an initial $\mathrm{pH}$ of 5.5. Diffusible pigments are not formed. Does not degrade starch, Tween 20 or 80 or xanthine. Acid is formed from D-arabinose, D-galactose, D-glucose, glycerol, myo-inositol, D-mannose and Dxylose, but not from D-lactose, D-maltose, D-mannitol, $\alpha$ L-rhamnose or sodium citrate. D-Arabinose, D-cellobiose, meso-erythritol (weak), D-fructose, D-galactose, D-glucose, glycerol, myo-inositol (weak), D-lactose, D-maltose, Dmelezitose, D-raffinose, D-ribose, D-sorbose, D-sucrose (weak), D-trehalose and D-xylose are used as sole carbon sources for energy and growth, but adonitol and sodium propionate are not. Growth occurs at an initial $\mathrm{pH}$ between 3.5 and $9 \cdot 5$, and at $17-37^{\circ} \mathrm{C}$, but not at 10 or $45^{\circ} \mathrm{C}$. Additional phenotypic properties are shown in Table 1. Chemotaxonomic properties are typical of the genus Nocardia. The major cellular fatty acids are $\mathrm{C}_{16: 1} \omega 7 \mathrm{c}$ $(12 \cdot 4 \%), \mathrm{C}_{16: 0}(24 \cdot 8 \%), \mathrm{C}_{18: 1} \omega 9 c(12 \cdot 3 \%), \mathrm{C}_{18: 0}(11 \cdot 0 \%)$ and 10-methyl $\mathrm{C}_{18: 0}(27 \cdot 3 \%)$. The species description is based on a single strain, which therefore serves as the type strain.

The type strain, $43401^{\mathrm{T}}\left(=\right.$ CGMCC $\left.4.1905^{\mathrm{T}}=\mathrm{JCM} 12861^{\mathrm{T}}\right)$ was isolated from the rhizosphere of goose-grass (Eleusine indica) that was growing next to a copper mine in Wushan, Jiangxi Province, China.

\section{Description of Nocardia miyunensis sp. nov.}

Nocardia miyunensis (mi.yun.en'sis. N.L. fem. adj. miyunensis referring to Miyun County in Beijing, the source of the type strain).

Aerobic, Gram-positive, catalase-positive, partially acidalcohol-fast, non-motile actinomycete that forms an extensively branched substrate mycelium that fragments into rod-shaped elements. A white to yellowish white substrate mycelium bears sparse to abundant, white to pink aerial hyphae on modified Sauton's agar. A yellowish brown substrate mycelium bearing white aerial hyphae is formed on oatmeal agar at an initial $\mathrm{pH}$ of 5.5. Diffusible pigments are not formed. Does not degrade starch, Tween 20 or 80 or xanthine. Acid is formed from D-galactose, D-glucose, glycerol, D-mannose and D-xylose, but not from Darabinose, myo-inositol, D-lactose, D-maltose, D-mannitol, $\alpha$-L-rhamnose or sodium citrate. D-Arabinose (weak), Dcellobiose, meso-erythritol (weak), D-fructose, D-galactose, D-glucose, glycerol, myo-inositol, D-lactose, D-maltose, Dmelezitose, $\alpha$-L-rhamnose, D-raffinose, D-ribose, D-sorbose, D-sucrose (weak), D-trehalose and D-xylose are used as sole carbon sources for energy and growth, but adonitol, D-mannitol, D-mannose and sodium propionate are not. Growth occurs at an initial $\mathrm{pH}$ between 4.5 and $9 \cdot 5$, and between 17 and $37^{\circ} \mathrm{C}$, but not at 10 or $45^{\circ} \mathrm{C}$. Additional phenotypic properties are shown in Table 1. Chemotaxonomic properties are typical of the genus Nocardia. The major cellular fatty acids are $\mathrm{C}_{16: 1} \omega 7 t(16 \cdot 4 \%), \mathrm{C}_{16: 0}$ $(27 \cdot 2 \%), \mathrm{C}_{18: 1} \omega 9 c(7 \cdot 7 \%), \mathrm{C}_{18: 0}(6 \cdot 4 \%)$ and 10-methyl $\mathrm{C}_{18: 0}(33.0 \%)$. The species description is based on a single strain, which therefore serves as the type strain.

The type strain, $117^{\mathrm{T}}\left(=\right.$ CGMCC $\left.4.1904^{\mathrm{T}}=\mathrm{JCM} 12860^{\mathrm{T}}\right)$, was isolated from a pine-forest soil sample collected in Miyun County, Beijing, People's Republic of China.

\section{Acknowledgements}

This work was supported through the Royal Society/Chinese Academy of Sciences Exchange Scheme (grant no. Q814) and by the HiTech Research and Development program of China (grant no. 2004AA227100). All of the authors are grateful to Professor Yongsheng Gao (Jiangxi Agricultural University, China) for providing some of the acidic soil samples.

\section{References}

Albuquerque de Barros, E. V. S., Manfio, G. P., Ribeiro Maitan, V., Mendes Bataus, L. A., Kim, S. B., Maldonado, L. A. \& Goodfellow, M. (2003). Nocardia cerradoensis sp. nov., a novel isolate from Cerrado soil in Brazil. Int J Syst Evol Microbiol 53, 29-33.

Bringmann, G., Noll, T. F., Dreyer, M., Grune, M., Wilde, C., Payne, G., Jones, A., Goodfellow, M. \& Fiedler, H. P. (2005). A first example of cryptic convergence in the biosynthesis of polyketides. J Antibiot (in press).

Chun, J. \& Goodfellow, M. (1995). A phylogenetic analysis of the genus Nocardia with $16 \mathrm{~S}$ rRNA gene sequences. Int J Syst Bacteriol 45, 240-245.

Ezaki, T., Hashimoto, Y. \& Yabuuchi, E. (1989). Fluorometric deoxyribonucleic acid-deoxyribonucleic acid hybridization in microdilution wells as an alternative to membrane filter hybridization in which radioisotopes are used to determine genetic relatedness among bacterial strains. Int J Syst Bacteriol 39, 224-229.

Felsenstein, J. (1981). Evolutionary trees from DNA sequences: a maximum likelihood approach. J Mol Evol 17, 368-376.

Felsenstein, J. (1985). Confidence limits on phylogenies: an approach using the bootstrap. Evolution 39, 783-791.

Felsenstein, J. (1993). PHYLIP (phylogeny inference package), version 3.6. Distributed by the author. Department of Genome Sciences, University of Washington, Seattle, USA.

Fitch, W. M. \& Margoliash, E. (1967). Construction of phylogenetic trees: a method based on mutation distances as estimated from cytochrome $\mathrm{c}$ sequences is of general applicability. Science 155, 279-284.

Goodfellow, M. (1971). Numerical taxonomy of some nocardioform bacteria. J Gen Microbiol 69, 33-80.

Goodfellow, M., Isik, K. \& Yates, E. (1999). Actinomycete systematics: an unfinished synthesis. Nova Acta Leopold NF80 (312), 47-82.

Gordon, R. E. \& Mihm, J. M. (1957). A comparative study of some strains received as nocardiae. J Bacteriol 73, 15-27.

Gordon, R. E., Barnett, D. A., Handerhan, J. E. \& Pang, C. H.-N. (1974). Nocardia coeliaca, Nocardia autotrophica, and the nocardin strain. Int J Syst Bacteriol 24, 54-63. 
Hamid, M. E., Maldonado, L., Eldin, G. S. S., Mohamed, M. F., Saeed, N. S. \& Goodfellow, M. (2001). Nocardia africana sp. nov., a new pathogen isolated from patients with pulmonary infections. J Clin Microbiol 39, 625-630.

Huang, Y., Cui, Q., Wang, L., Rodriguez, C., Quintana, E., Goodfellow, M. \& Liu, Z. (2004). Streptacidiphilus jiangxiensis sp. nov., a novel actinomycete isolated from acidic rhizosphere soil in China. Antonie van Leeuwenhoek 86, 159-165.

Kageyama, A., Poonwan, N., Yazawa, K., Mikami, Y. \& Nishimura, K. (2004a). Nocardia asiatica sp. nov., isolated from patients with nocardiosis in Japan and clinical specimens from Thailand. Int J Syst Evol Microbiol 54, 125-130.

Kageyama, A., Yazawa, K., Nishimura, K. \& Mikami, Y. (2004b). Nocardia inohanaensis sp. nov., Nocardia yamanashiensis sp. nov. and Nocardia niigatensis sp. nov., isolated from clinical specimens. Int J Syst Evol Microbiol 54, 563-569.

Kageyama, A., Yazawa, K., Mukai, A., Kohara, T., Nishimura, K., Kroppenstedt, R. M. \& Mikami, Y. (2004c). Nocardia araoensis sp. nov. and Nocardia pneumoniae sp. nov., isolated from patients in Japan. Int J Syst Evol Microbiol 54, 2025-2029.

Kageyama, A., Torikoe, K., Iwamoto, M. \& 7 other authors (2004d). Nocardia arthritidis sp. nov., a new pathogen isolated from a patient with rheumatoid arthritis in Japan. J Clin Microbiol 42, 2366-2371.

Kim, K. K., Roth, A., Andrees, S., Lee, S. T. \& Kroppenstedt, R. M. (2002). Nocardia pseudovaccinii sp. nov. Int J Syst Evol Microbiol 52, $1825-1829$.

Kimura, M. (1980). A simple method for estimating evolutionary rates of base substitutions through comparative studies of nucleotide sequences. J Mol Evol 16, 111-120.

Kinoshita, N., Homma, Y., Igarashi, M., Ikeno, S., Hori, M. \& Hamada, M. (2001). Nocardia vinacea sp. nov. Actinomycetologica 15, $1-5$.

Kluge, A. G. \& Farris, F. S. (1969). Quantitative phyletics and the evolution of anurans. Syst Zool 18, 1-32.

Küster, E. (1959). Outline of a comparative study of criteria used in characterisation of the actinomycetes. Int Bull Bacteriol Nomencl Taxon 9, 97-104.

Lechevalier, M. P. \& Lechevalier, H. (1970). Chemical composition as a criterion in the classification of aerobic actinomycetes. Int J Syst Bacteriol 20, 435-443.

Lechevalier, M. P., De Bièvre, C. \& Lechevalier, H. A. (1977). Chemotaxonomy of aerobic actinomycetes: phospholipid composition. Biochem Syst Ecol 5, 249-260.

Li, W.-J., Jiang, Y., Kroppenstedt, R. M., Xu, L.-H. \& Jiang, C.-L. (2004). Nocardia alba sp. nov., a novel actinomycete strain isolated from soil in China. Syst Appl Microbiol 27, 308-312.

Lu, Z., Liu, Z., Wang, L., Zhang, Y., Qi, W. \& Goodfellow, M. (2001). Saccharopolyspora flava sp. nov. and Saccharopolyspora thermophila sp. nov., novel actinomycetes from soil. Int J Syst Evol Microbiol 51, 319-325.

Maldonado, L., Hookey, J. V., Ward, A. C. \& Goodfellow, M. (2000). The Nocardia salmonicida clade, including descriptions of Nocardia cummidelens sp. nov., Nocardia fluminea sp. nov. and Nocardia soli sp. nov. Antonie van Leeuwenhoek 78, 367-377.

Mordarska, H., Mordarski, M. \& Goodfellow, M. (1972). Chemotaxonomic characters and classification of some nocardioform bacteria. J Gen Microbiol 71, 77-86.
Orchard, V. A. (1979). Effect of sewage sludge additions on Nocardia in soil. Soil Biol Biochem 11, 217-220.

Orchard, V. A. (1981). The ecology of Nocardia and related taxa. Zentbl Bakteriol Suppl II, 167-180.

Orchard, V. A. \& Goodfellow, M. (1980). Numerical classification of some named strains of Nocardia asteroides and related isolates from soil. J Gen Microbiol 118, 295-312.

Rainey, F. A., Ward-Rainey, N., Kroppenstedt, R. M. \& Stackebrandt, E. (1996). The genus Nocardiopsis represents a phylogenetically coherent taxon and a distinct actinomycete lineage: proposal of Nocardiopsaceae fam. nov. Int J Syst Bacteriol 46, 1088-1092.

Saintpierre-Bonaccio, D., Maldonado, L. A., Amir, H., Pineau, R. \& Goodfellow, M. (2004). Nocardia neocaledoniensis sp. nov., a novel actinomycete isolated from a New-Caledonian brown hypermagnesian ultramafic soil. Int J Syst Evol Microbiol 54, 599-603.

Saitou, N. \& Nei, M. (1987). The neighbor-joining method: a new method for reconstructing phylogenetic trees. Mol Biol Evol 4, 406-425.

Stackebrandt, E., Rainey, F. A. \& Ward-Rainey, N. L. (1997). Proposal for a new hierarchic classification system, Actinobacteria classis nov. Int J Syst Bacteriol 47, 479-491.

Thompson, J. D., Gibson, T. J., Plewniak, F., Jeanmougin, F. \& Higgins, D. G. (1997). The CLUSTAL_X Windows interface: flexible strategies for multiple sequence alignment aided by quality analysis tools. Nucleic Acids Res 25, 4876-4882.

Wang, Y., Zhang, Z. S., Ruan, J. S., Wang, Y. M. \& Ali, S. M. (1999). Investigation of actinomycete diversity in the tropical rainforests of Singapore. J Ind Microbiol Biotechnol 23, 178-187.

Wang, L., Huang, Y., Cui, O., Xie, Q., Zhang, Y. \& Liu, Z. (2003). Isolation of acidophilic and acidoduric streptomycetes using a dispersion and differential centrifugation approach. Microbiologia 30, 104-106 (in Chinese).

Wayne, L. G., Brenner, D. J., Colwell, R. R. \& 9 other authors (1987). International Committee on Systematic Bacteriology. Report of the ad hoc committee on reconciliation of approaches to bacterial systematics. Int J Syst Bacteriol 37, 463-464.

Yassin, A. F., Rainey, F. A., Brzezinka, H., Burghardt, J., Lee, H. J. \& Schaal, K. P. (1995). Tsukamurella inchonensis sp. nov. Int J Syst Bacteriol 45, 522-527.

Yassin, A. F., Rainey, F. A., Burghardt, J., Brzezinka, H., Mauch, M. \& Schaal, K. P. (2000a). Nocardia paucivorans sp. nov. Int J Syst Evol Microbiol 50, 803-809.

Yassin, A. F., Rainey, F. A., Mendrock, U., Brzezinka, H. \& Schaal, K. P. (2000b). Nocardia abscessus sp. nov. Int J Syst Evol Microbiol 50, 1487-1493.

Yassin, A. F., Rainey, F. A. \& Steiner, U. (2001a). Nocardia cyriacigeorgici sp. nov. Int J Syst Evol Microbiol 51, 1419-1423.

Yassin, A. F., Rainey, F. A. \& Steiner, U. (2001b). Nocardia ignorata sp. nov. Int J Syst Evol Microbiol 51, 2127-2131.

Yassin, A. F., Sträubler, B., Schumann, P. \& Schaal, K. P. (2003). Nocardia puris sp. nov. Int J Syst Evol Microbiol 53, 1595-1599.

Zhang, J., Liu, Z. \& Goodfellow, M. (2003). Nocardia caishijiensis sp. nov., a novel soil actinomycete. Int J Syst Evol Microbiol 53, 999-1004.

Zhang, J., Liu, Z. \& Goodfellow, M. (2004). Nocardia xishanensis sp. nov., a novel actinomycete isolated from soil. Int J Syst Evol Microbiol 54, 2301-2305. 